\title{
HUBUNGAN KECERDASAN EMOSIONAL DAN STATUS GIZI DENGAN PRESTASI BELAJAR SISWA SMA NEGERI UNGGUL KOTA SUBULUSSALAM
}

\author{
M Rizki Ramadhan ${ }^{1}$, Husnah $^{2}$, Zulfa Zahra ${ }^{3}$ \\ ${ }^{1)}$ Mahasiswa Fakultas Kedokteran Universitas Syiah Kuala \\ 2) Staff Pengajar Bagian Ilmu Gizi Fakultas Kedokteran Universitas Syiah Kuala \\ ${ }^{3)}$ Staff Pengajar Bagian Ilmu Kedokteran Jiwa Fakultas Kedokteran Universitas Syiah Kuala \\ Corresponding Author : mrramadhan24@gmail.com
}

\begin{abstract}
Abstrak
Prestasi belajar dipengaruhi oleh beberapa faktor yaitu faktor internal seperti psikologi, jasmani, fisiologi, panca indra dan faktor eksternal meliputi lingkungan dan sosial. Salah satu faktor psikologis yang penting dapat mempengaruhi prestasi belajar adalah kecerdasan emosional. Penelitian ini bertujuan untuk mengetahui hubungan kecerdasan emosional dan status gizi dengan prestasi belajar siswa SMA Negeri Unggul Subulussalam. Jenis penelitian adalah analitik observasional dengan desain cross sectional. Teknik pengambilan sampel secara stratified random sampling dari tanggal 14 sampai 20 Oktober 2017 dengan jumlah sampel 172 siswa. Data yang diambil meliputi kecerdasan emosional menggunakan kuesioner kecerdasan emosional, status gizi dengan indeks massa tubuh dan prestasi belajar dengan nilai raport. Analisis data menggunakan uji spearman correlation. Hasil penelitian di dapatkan kecerdasan emosional terbanyak adalah baik 123 siswa (71,5\%), status gizi normal 127 siswa $(73,8 \%)$ serta prestasi belajar baik 162 siswa $(94,2 \%)$. Hasil analisis data antara hubungan kecerdasan emosional dengan prestasi belajar diperoleh $p$ value 0.028 dan $\mathrm{r} 0.167$ hal ini menunjukkan terdapat hubungan antara kecerdasan emosional dengan prestasi belajar. Status gizi dengan prestasi belajar diperoleh $p$ value 0,281 dan $r-0,094$ hal ini menunjukkan tidak terdapat hubungan antara status gizi dengan prestasi belajar. Dapat disimpulkan bahwa kecerdasan emosional berhubungan dengan prestasi belajar dan status gizi tidak berhubungan dengan prestasi belajar.
\end{abstract}

Kata kunci : kecerdasan emosional, status gizi, prestasi belajar.

\section{The Relation Of Emotional Intelligence And Nutrition Status With Learning Achievements Of Superior High School Students Subulussalam City}

\begin{abstract}
Learning achievement is influenced by several factors, the internal factors such as physical, psychology, physiology, and human sense. The external factors such as environmental and social issue. One of physiological factor affected the learning achievement is emotional quotient. The aim of this study is to determine a relationship of emotional quotient and nutritional status with learning achievement of students at Unggul Senior High School Subulussalam. The kind of this study is analytic observational by cross sectional design. The sampling technique stratified random sampling from 14-20 October 2017 with a sample of 172 students. The data was taken include emotional quotient using quisionaire of emotional quotient, nutritional status using Body Mass Indeks (BMI) and learning achievement using raport value. The data analysis used the correlation spearman rank. The result of data
\end{abstract}


emotional quotient good is 123 students $(71,5 \%)$, nutritional status normal is 127 students $(73,8 \%)$ and learning achievement good is 162 students $(94,2 \%)$. The result of data analysis between emotional quotient with learning achievement show that $p$ value 0,028 and $r 0,167$, there is relationship between emotional quotient with learning achievement. Nutritional status and learning achievement show that $\mathrm{p}$ value 0,281 and $\mathrm{r}-0,094$, there was no correlation between nutritional status and learning achievement. Based on the result of the study, there is relationship emotional quotient with learning achievement but there was no correlation nutritional status with learning achievement at Unggul Senior High School Subulussalam.

Keyword : emotional quotient, nutritional status, learning achievement

\section{PENDAHULUAN}

Sebagai negara yang berkembang Indonesia sedang berusaha untuk meningkatkan kualitas sumber daya manusia dengan cara meningkatkan mutu pendidikan. Pendidikan yang berkualitas biasanya ditandai dengan prestasi belajar yang baik sehingga prestasi belajar tidak bisa dipisahkan dari proses belajar. Prestasi belajar juga merupakan salah satu indikator untuk menilai kualitas siswa. ${ }^{1}$

Banyak faktor yang mempengaruhi prestasi belajar yaitu faktor internal seperti psikologi, jasmani, fisiologis dan panca indra dan faktor eksternal meliputi lingkungan dan sosial. Salah satu faktor psikologis yang penting dapat mempengaruhi prestasi belajar adalah kecerdasan emosional. ${ }^{2}$

Kecerdasan emosional yang tinggi dapat memotivasi siswa dalam proses belajar, sedangkan siswa yang kurang kecerdasan emosionalnya akan merasa lebih sulit untuk memotivasi proses belajar mereka. Roy dkk tahun 2013 di Patna, India menyatakan bahwa adanya hubungan positif antara kecerdasan emosional dan prestasi belajar. Penelitian menunjukkan dari 105 siswa, didapatkan sebanyak 54,2\% mempunyai kecerdasan emosional tinggi dan $23.8 \%$ prestasi belajar tinggi. Kecerdasan emosional antara siswa yang memiliki prestasi belajar yang tinggi, rata-rata dan rendah berbeda antara satu dan lainnya. ${ }^{3}$

Kecerdasan dipengaruhi faktor genetik dan faktor lingkungan termasuk asupan gizi. Faktor genetik sulit untuk dimodifikasi sehingga faktor lingkungan memegang peranan yang penting dalam meningkatkan kecerdasan. Salah satu bentuk modifikasi faktor lingkungan adalah dengan memberikan rangsangan terus menerus. Kebutuhan gizi yang baik sejak di dalam kandungan sampai remaja sangat diperlukan terutama untuk perkembangan otak, pencegahan dan pengobatan penyakit yang dapat mempengaruhi perkembangan kecerdasan, dan keterampilan fisik untuk melakukan aktivitas sehari-hari.

Status gizi juga merupakan faktor yang berpengaruh terhadap prestasi seseorang. Rendahnya status gizi berdampak pada kualitas sumber daya manusia. ${ }^{4}$ Hasil Riset Kesehatan Dasar (RISKESDAS) di Indonesia tahun 2013, prevalensi kurus menurut IMT/U pada remaja umur 13-15 tahun adalah sebesar $11,1 \%$ terdiri dari 3,3\% sangat kurus dan 7,8\% kurus. Prevalensi sangat kurus pada umur 13-15 tahun paling tinggi di Nusa Tenggara Timur $(9,2 \%)$ dan paling rendah di Bangka Belitung (1,4\%). Pada umur 16-18 tahun, prevalensi kurus menurut IMT/U secara nasional sebesar 9,4\% terdiri dari 1,9\% sangat kurus dan 7,5\% kurus. Riset Kesehatan Dasar (RISKESDAS) Provinsi Aceh tahun 2013, prevalensi kurus menurut IMT/U pada remaja umur 13-15 tahun sebesar 12,9\% terdiri dari 3,5\% sangat kurus dan 9,4\% kurus. Prevalensi kurus menurut IMT/U pada remaja umur 16-18 tahun sebesar $8,5 \%$ terdiri dari $2,0 \%$ sangat kurus dan $6,5 \%$ kurus. $^{5}$

Gizi merupakan salah satu faktor penentu utama kualitas Sumber Daya Manusia. Status gizi yang baik akan mempengaruhi proses pertumbuhan dan perkembangan anak, salah 
satunya dapat meningkatkan kemampuan intelektual yang akan berdampak pada prestasi belajar di sekolah. Penelitian Setiawati dkk tahun 2007, menyatakan bahwa status gizi dan kecerdasan emosional mempunyai hubungan terhadap prestasi belajar. Penelitian menunjukkan dari 126 siswa, didapatkan sebanyak 60,3\% mempunyai kecerdasan emosional tinggi, $73 \%$ dengan status gizi baik, dan $29,4 \%$ prestasi belajar tinggi. ${ }^{2}$

\section{METODE PENELITIAN}

Jenis penelitian adalah analitik observasional dengan pendekatan cross sectional yang dilakukan di SMA Negeri Unggul Kota Subulussalam pada tanggal 14 sampai 20 Oktober 2017. Populasi penelitian adalah siswa SMA Negeri Unggul Kota Subulussalam kelas XI dan XII tahun ajaran 2017/2018 yang diambil secara simple random sampling kemudian dilanjutkan dengan teknik stratified random sampling. Didapatkan sampel sebanyak 172 siswa. Nilai rapor siswa didapat dari bagian kemahasiswaan SMA Negeri Unggul Kota Subulussalam, data status gizi dengan mengukur tinggi badan dan menimbang berat badan, data kecerdasan emosional didapatkan dari pengisian kuisioner kecerdasan emosional yang telah diuji validitas. Analisis statistik dengan analisa univariat untuk distribusi frekuensi dan analisa bivariat uji Spearman.

\section{HASIL PENELITIAN}

Karakteristik responden pada penelitian menggambarkan jenis kelamin, umur, kelas dan tempat tinggal disajikan dalam tabel 1.1

Tabel 1.1 Karakteristik responden berdasarkan jenis kelamin, umur, kelas, dan tempat tinggal.

\begin{tabular}{ccc}
\hline \multicolumn{1}{c}{ Karakteristik } & $\mathrm{n}=172$ & $\%$ \\
\hline Jenis Kelamin & & \\
Laki-Laki & 58 & 33,7 \\
Perempuan & 114 & 66,3 \\
Umur (tahun) & & \\
14 & 1 & 0,6 \\
15 & 16 & 9.3 \\
16 & 74 & 43,0 \\
17 & 76 & 44,2 \\
18 & 5 & 2,9 \\
Kelas & & \\
XI & 100 & 58,1 \\
XII & 72 & 41,9 \\
Tempat Tinggal & & \\
Asrama & 19 & 11 \\
Rumah & 153 & 89 \\
\hline
\end{tabular}

Berdasarkan tabel 1.1 menunjukkan bahwa jumlah responden terbanyak adalah perempuan 114 siswi (66,3\%), usia terbanyak adalah 17 tahun yaitu 76 siswa $(44,2 \%)$, responden terbanyak adalah kelas XI yaitu 100 siswa $(58,1 \%)$ dan tempat tinggal siswa dominan adalah dirumah yaitu 153 orang (89\%).

Kecerdasan emosional, status gizi dan prestasi belajar siswa SMA Negeri Unggul Kota Subulussalam dapat dilihat pada tabel 1.2 dibawah ini. 
Tabel 1.2 Distribusi frekuensi kecerdasan emosional, status gizi dan prestasi belajar siswa SMA Negeri Unggul Kota Subulussalam

\begin{tabular}{|c|c|c|}
\hline \multirow{2}{*}{\multicolumn{3}{|c|}{$\begin{array}{l}\text { Variabel } \\
\text { Kecerdasan Emosional } \\
\text { Kurang }\end{array}$}} \\
\hline & & \\
\hline Cukup & 0 & 0 \\
\hline Baik & 49 & 28,5 \\
\hline $\begin{array}{l}\text { Status gizi } \\
\text { Sangat kurus }\end{array}$ & 123 & 71,5 \\
\hline Kurus & 1 & 0,6 \\
\hline Normal & 13 & 7,6 \\
\hline Gemuk & 127 & 73,8 \\
\hline Obesitas & 19 & 11 \\
\hline $\begin{array}{l}\text { Prestasi belajar } \\
\text { Cukup }\end{array}$ & 12 & 7 \\
\hline Baik & 0 & 0 \\
\hline Sangat Baik & $\begin{array}{c}162 \\
10\end{array}$ & $\begin{array}{c}94,2 \\
5,8\end{array}$ \\
\hline
\end{tabular}

Berdasarkan tabel 1.2 menunjukkan bahwa dari 172 responden lebih dominan pada kecerdasan emosional baik yaitu 123 responden (71,5\%), status gizi normal yaitu 127 responden $(73,8 \%)$, dan prestasi belajar baik sebanyak 162 responden $(94,2 \%)$.

Tabel 4.3 Distribusi jenis kelamin dan kecerdasan emosional

\begin{tabular}{cccccccc}
\hline \multirow{2}{*}{ Jenis Kelamin } & \multicolumn{9}{c}{ Kecerdasan Emosional } \\
\cline { 2 - 8 } & \multicolumn{2}{c}{ Baik } & \multicolumn{2}{c}{ Sedang } & \multicolumn{2}{c}{ Total } \\
\cline { 2 - 7 } & 39 & 67,2 & 19 & $\%$ & $\mathrm{n}$ & $\%$ \\
\hline Laki-Laki & 39 & 30,8 & 58 & 100 \\
Perempuan & 84 & 73,7 & 30 & 26,3 & 114 & 100 \\
\hline
\end{tabular}

Berdasarkan tabel 1.3 menunjukkan bahwa dominan siswa perempuan dan cenderung memiliki kecerdasan emosional baik sebanyak 84 responden $(73,3 \%)$.

Tabel 4.4 Distribusi tempat tinggal dan kecerdasan emosional

\begin{tabular}{ccccccc}
\hline \multirow{2}{*}{ Tempat Tinggal } & \multicolumn{6}{c}{ Kecerdasan Emosional } \\
\cline { 2 - 7 } & \multicolumn{2}{c}{ Baik } & n Sedang & $\%$ & $\mathrm{n}$ & Total \\
\cline { 2 - 7 } & 110 & 71,9 & 43 & 28,1 & 153 & 100 \\
Rumah & 13 & 68,4 & 6 & 31,6 & 19 & 100 \\
Asrama & & & & &
\end{tabular}

Berdasarkan tabel 1.4 menunjukkan bahwa siswa lebih dominan tinggal dirumah dan cenderung memiliki kecerdasan emosional baik sebanyak 110 responden $(71,9 \%)$.

Tabel 1.5 Distribusi jenis kelamin berdasarkan status gizi

\begin{tabular}{|c|c|c|c|c|c|c|c|c|c|c|c|c|}
\hline \multirow{3}{*}{ Jenis kelamin } & \multicolumn{10}{|c|}{ Status Gizi } & \multirow{2}{*}{\multicolumn{2}{|c|}{ Total }} \\
\hline & \multicolumn{2}{|c|}{ Obesitas } & \multicolumn{2}{|c|}{ Gemuk } & \multicolumn{2}{|c|}{ Normal } & \multicolumn{2}{|c|}{ Kurus } & \multicolumn{2}{|c|}{$\begin{array}{l}\text { Sangat } \\
\text { Kurus }\end{array}$} & & \\
\hline & $\mathrm{n}$ & $\%$ & $\mathrm{n}$ & $\%$ & $\mathrm{n}$ & $\%$ & $\mathrm{n}$ & $\%$ & $\mathrm{n}$ & $\%$ & $\mathrm{n}$ & $\%$ \\
\hline Laki-Laki & 3 & 5,2 & 6 & 10,3 & 43 & 74,1 & 6 & 10,3 & 0 & 0 & 58 & 100 \\
\hline Perempuan & 9 & 7,9 & 13 & 11,4 & 84 & 73,7 & 7 & 6,1 & 1 & 0,9 & 114 & 100 \\
\hline
\end{tabular}


Berdasarkan tabel 1.5 menunjukkan bahwa dominan siswa perempuan dan cenderung memiliki status gizi normal yaitu 84 responden $(73,3 \%)$.

Tabel 1.6 Distribusi tempat tinggal berdasarkan kecerdasan emosional

\begin{tabular}{|c|c|c|c|c|c|c|c|c|c|c|c|c|}
\hline \multirow{3}{*}{$\begin{array}{l}\text { Tempat } \\
\text { Tinggal }\end{array}$} & \multicolumn{10}{|c|}{ Status Gizi } & \multirow{2}{*}{\multicolumn{2}{|c|}{ Total }} \\
\hline & \multicolumn{2}{|c|}{ Obesitas } & \multicolumn{2}{|c|}{ Gemuk } & \multicolumn{2}{|c|}{ Normal } & \multicolumn{2}{|c|}{ Kurus } & \multicolumn{2}{|c|}{$\begin{array}{l}\text { Sangat } \\
\text { Kurus }\end{array}$} & & \\
\hline & $\mathrm{n}$ & $\%$ & $\mathrm{n}$ & $\%$ & $\mathrm{n}$ & $\%$ & $\mathrm{n}$ & $\%$ & $\mathrm{n}$ & $\%$ & $\mathrm{n}$ & $\%$ \\
\hline Rumah & 8 & 5,2 & 19 & 12,4 & 113 & 73,9 & 12 & 7,8 & 1 & 0,70 & 153 & 100 \\
\hline Asrama & 4 & 21,1 & 0 & 0 & 14 & 73,7 & 1 & 5,3 & 0 & & 19 & 100 \\
\hline
\end{tabular}

Berdasarkan tabel 1.6 menunjukkan bahwa siswa dominan tinggal dirumah dan cenderung memiliki status gizi normal sebanyak 113 responden $(73,9 \%)$.

Hubungan kecerdasan emosional dengan prestasi belajar siswa SMA Negeri Unggul Kota Subulussalam dapat dilihat pada tabel 1.7 dibawah ini.

Tabel 1.7 Hubungan kecerdasan emosional dengan prestasi belajar siswa SMA Negeri Unggul Kota Subulussalam

\begin{tabular}{|c|c|c|c|c|c|c|c|c|}
\hline \multirow{3}{*}{$\begin{array}{c}\text { Kecerdasan } \\
\text { Emosional }\end{array}$} & \multicolumn{8}{|c|}{ Prestasi Belajar } \\
\hline & \multicolumn{2}{|c|}{ Sangat Baik } & \multicolumn{2}{|c|}{ Baik } & \multicolumn{2}{|c|}{ Total } & \multirow{2}{*}{ P value } & \multirow[b]{2}{*}{$r$} \\
\hline & $\mathrm{n}$ & $\%$ & $\mathrm{n}$ & $\%$ & $\mathrm{n}$ & $\%$ & & \\
\hline Baik & 7 & 5,7 & 116 & 94,3 & 123 & 100 & \multirow{2}{*}{0.028} & \multirow{2}{*}{0.167} \\
\hline Cukup & 3 & 6,1 & 46 & 93,9 & 49 & 100 & & \\
\hline
\end{tabular}

Berdasarkan tabel 1.7 menunjukkan bahwa siswa dominan memiliki kecerdasan emosional baik dan cenderung berprestasi belajar baik sebanyak 116 siswa (94,3\%). Hasil analisis uji spearman correlation didapatkan nilai $p$ value $=0,028(\alpha<0,05)$ menunjukkan terdapat hubungan antara kecerdasan emosional dengan prestasi belajar pada siswa SMA Negeri Unggul Subulussalam dan $r=0,167$ menunjukkan terdapat hubungan yang lemah yang berarti kedua variabel memiliki hubungan searah yaitu jika kecerdasan emosional tinggi maka prestasi belajar juga akan tinggi.

Hubungan status gizi dengan prestasi belajar siswa SMA Negeri Unggul Kota Subulussalam dapat dilihat pada tabel 1.8 dibawah ini.

Tabel 1.8 Hubungan status gizi dengan prestasi belajar siswa SMA Negeri Unggul

Kota Subulussalam

\begin{tabular}{ccccccccc}
\hline & \multicolumn{8}{c}{ Prestasi Belajar } \\
\cline { 2 - 8 } Status Gizi & \multicolumn{7}{c}{ Sangat Baik } & \multicolumn{7}{c}{ Baik } & \multicolumn{2}{c}{ Total } & \multirow{2}{*}{ P value } & $r$ \\
\cline { 2 - 8 } & $\mathrm{n}$ & $\%$ & $\mathrm{n}$ & $\%$ & $\mathrm{n}$ & $\%$ & & \\
\hline Obesitas & 0 & 0 & 12 & 100 & 12 & 100 & & \\
Gemuk & 1 & 5,3 & 18 & 94,7 & 19 & 100 & & \\
Normal & 9 & 7,1 & 118 & 92,9 & 127 & 100 & 0.218 & $-0,094$ \\
Kurus & 0 & 0 & 13 & 100 & 13 & 100 & & \\
Sangat kurus & 0 & 0 & 1 & 100 & 1 & 100 & & \\
\hline
\end{tabular}

Berdasarkan tabel 1.8 diatas bahwa siswa dominan memiliki status gizi normal dan cenderung berprestasi belajar baik yaitu 118 siswa (92,9\%). Hasil analisis uji sprearman correlation didapatkan nilai $p$ value $=0,218(\alpha>0,05)$, dan nilai $r=-0,094$. Hal ini 
menunjukkan tidak terdapat hubungan antara status gizi dan prestasi belajar siswa SMA Negeri Unggul Subulussalam.

\section{PEMBAHASAN}

Hasil penelitian menunjukkan bahwa siswa SMA Negeri Unggul Subulussalam dominan perempuan serta tempat tinggal dirumah dengan kecerdasan emosional baik. Hal ini sejalan dengan penelitian Setiawati dkk terhadap siswa SMP yang menyatakan bahwa perempuan lebih banyak memiliki kecerdasan emosional tinggi. ${ }^{2}$ Hal ini bisa disebabkan oleh karena jumlah sampel perempuan lebih banyak dari pada laki-laki. Penelitian ini tidak sejalan dengan penelitian Zaki yang menyatakan bahwa kecerdasan emosional siswa pendidikan asrama lebih tinggi dari pada kecerdasan emosional siswa pendidikan regular. Hal ini disebabkan karena sedikitnya jumlah sampel penelitian yang tinggal di asrama. Pendidikan reguler yang dimaksudkan pada penelitian Zaki adalah pendidikan yang dijalani oleh siswa selama setengah hari sesuai kurikulum standar pemerintah. Sedangkan SMA Negeri Unggul Kota Subulussalam menerapkan sistem full day school yang berbeda dengan sekolah pendidikan regular pada umumnya. ${ }^{9}$

Hasil penelitian ini menunjukkan bahwa responden dominan memiliki kecerdasan emosional baik. Penelitian Fauzi dkk di Bandar Lampung terhadap siswa SMP negeri 22 yang terdiri dari 107 responden yang memiliki kecerdasan emosional baik sebanyak 50 responden, kecerdasan emosional cukup 32 responden dan kecerdasan emosional kurang 25 responden. ${ }^{10}$ Hasil penelitian ini sejalan dengan penelitian Kalapriya terhadap 100 responden menunjukkan kecerdasan emosional baik 11 responden, kecerdasan emosional cukup 57 responden, kecerdasan emosional kurang 29 responden dan kecerdasan emosional sangat kurang 3 responden. ${ }^{11}$

Seseorang dengan kecerdasan emosional yang baik, mampu menyelesaikan dan bertanggung jawab penuh pada pekerjaan dan bersosiatif. ${ }^{12}$ Kecerdasan emosional bukan didasarkan pada kepintaran seorang anak melainkan pada suatu yang disebut karakter atau karakteristik pribadi. Kecerdasan emosional merupakan karakteristik seseorang sebagai suatu jenis kecerdasan yang amat perlu di tingkatkan. Kecerdasan emosional mencakup kemampuan yang berbeda-beda dan saling melengkapi dengan kemampuan lainnya. ${ }^{13}$ Hasil penelitian menunjukkan bahwa siswa SMA Negeri Unggul Subulussalam dominan perempuan dan tinggal dirumah cenderung memiliki status gizi normal. Hal ini sejalan dengan penelitian Padriyani yang menyatakan bahwa perempuan cenderung memiliki status gizi normal. Hal ini bisa disebabkan oleh banyaknya sampel perempuan dan juga dominan responden tinggal dirumah bersama orang tua yang menjamin pola makan sehari-harinya. Faktor ekonomi juga berpengaruh terhadap asupan makanan, jika pendapatan keluarga rendah maka jumlah dah jenis makanan yang diperoleh juga cenderung buruk. ${ }^{14}$

Hasil penelitian menunjukan bahwa responden dominan memiliki status gizi normal. Peneitian Dwi Y terhadap siswa sekolah dasar yang terdiri dari 67 siswa menunjukan bahwa sebanyak 10 siswa memiliki status gizi sangat kurus, 33 siswa status gizi kurus, 20 siswa status gizi normal dan 4 siswa status gizi gemuk. ${ }^{6}$ Status gizi adalah hasil masukan zat gizi makanan dan pemanfaatannya di dalam tubuh seseorang. Untuk mencapai status gizi yang baik diperlukan pangan yang mengandung zat gizi cukup dan aman untuk dikonsumsi. ${ }^{15}$

Status gizi menjadi sebuah indikator terhadap baik tidaknya pemenuhan kebutuhan gizi pada anak. Kebutuhan gizi yang dapat terpenuhi dengan baik maka akan terwujud status gizi yang baik, sedangkan apabila kebutuhan gizi tidak terpenuhi maka akan menjadi status gizi yang kurang baik. ${ }^{16}$ Hasil penelitian menunjukkan bahwa responden terbanyak memiliki prestasi belajar baik. Penelitian yang Ristiyati terhadap 70 siswa sekolah dasar di Semarang siswa yang memiliki prestasi belajar baik 33 siswa dan prestasi belajar kurang 37 siswa. ${ }^{17}$ Penelitian Qurniyawati terhadap mahasiswa kebidanan menunjukan bahwa dari 56 responden 
yang memiliki prestasi belajar sangat baik 8 responden, baik 40 responden dan cukup 8 responden. ${ }^{18}$

Prestasi belajar merupakan penilaian terhadap hasil belajar siswa. Prestasi belajar adalah penguasaan pengetahuan atau keterampilan yang dikembangkan oleh mata pelajaran lazimnya ditunjukkan dengan hasil tes atau nilai angka yang diberikan oleh guru. ${ }^{19}$ Prestasi belajar adalah suatu hal yang tidak dapat dipisahkan dengan kegiatan belajar karena kegiatan belajar merupakan proses sedangkan prestasi belajar merupakan hasil dari proses belajar tersebut. $^{20}$

\section{Hubungan Kecerdasan Emosional Dengan Prestasi Belajar}

Hasil penelitian menunjukkan bahwa terdapat hubungan antara kecerdasan dengan prestasi belajar SMA Negeri Unggul Subulussalam dengan kekuatan hubungan lemah. Hal ini sejalan dengan penelitian Qurniyawati bahwa terdapat hubungan antara kecerdasan emosional dan prestasi belajar. ${ }^{10}$

Kecerdasan emosional menyediakan pemahaman yang lebih mendalam dan lebih utuh tentang diri sendiri dan orang lain disekitar kita, perlu diketahui bahwa kecerdasan emosional memiliki peran yang sangat penting untuk mencapai kecerdasan disekolah, tempat kerja dan berkomunikasi di lingkungan masyarakat. ${ }^{20}$

Dalam proses pembelajaran, kecerdasan intelektual dan kecerdasan emosional saling melengkapi sehingga dengan keseimbangan antara kecerdasan intelektual dan kecerdasan emosional merupakan kunci keberhasilan belajar siswa disekolah. ${ }^{20}$

Kecerdasan emosional rendah akan mengakibatkan seseorang tidak dapat menggunakan kemampuan kognitifnya dengan potensi yang maksimal dan biasanya cenderung lebih mudah putus asa. Hal ini dikarenakan banyak faktor-faktor yang mempengaruhi kecerdasan emosional diantaranya umur, genetik, lingkungan, pola asuh dll. Sedangkan untuk kecerdasan emosional tinggi akan mempengaruhi keterampilan kognitif yang terdapat dalam aspek-aspek prestasi akademik karena keterampilan kognitif dapat menyelesaikan kemampuan siswa dalam mengelola sistem belajarnya. ${ }^{21}$

\section{Hubungan Status Gizi Dengan Prestasi Belajar}

Hasil penelitian menunjukkan tidak terdapat hubungan antara status gizi dengan prestasi belajar siswa SMA Negeri Unggul Kota Subulussalam. Penelitian ini sejalan dengan penelitian Padriyani dkk bahwa tidak terdapat hubungan antara status gizi dengan prestasi belajar. ${ }^{14}$ Penelitian ini juga sejalan dengan penelitian Setiawati dkk bahwa tidak terdapat hubungan antara status gizi dengan prestasi belajar. Persamaan penelitian ini dengan penelitian terdahulu yaitu hanya memperhitungkan status gizi dan tidak memperhitungkan faktor-faktor lainnya seperti faktor lingkungan dan sosial ekonomi. ${ }^{2}$

Hasil penelitian ini berbeda dengan penelitian Khairunnisa yang menyatakan bahwa terdapat hubungan antara status gizi mahasiswa Akademi Kebidanan di Bekasi dengan nilai indeks prestasi kumulatif. Perbedaan ini dapat disebabkan oleh faktor lingkungan dimana yang menjadi sampel pada penelitian Khairunnisa memiliki waktu belajar dan status gizi yang cukup terkontrol dikarenakan tinggal dan makan dengan katering asrama. ${ }^{22}$

Penelitian ini bertolak belakang dengan teori bahwa keadaan fisiologis sangat berpengaruh terhadap keberhasilan belajar seseorang. Orang yang ada dalam keadaan segar jasmaninya akan berbeda belajarnya dari orang yang dalam keadaan lelah. Anak-anak yang kekurangan gizi ternyata kemampuannya berada dibawah anak-anak yang gizi tercukupi. Anak-anak yang kekurangan gizi mudah lelah, mudah mengantuk, dan tidak mudah menerima pelajaran. ${ }^{23}$ Akibat status gizi kurang dapat menyebabkan perkembangan otak yang tidak sempurna sehingga menyebabkan kognitif dan kemampuan belajar terganggu. ${ }^{24}$ 
Terdapat lebih dari 100 milyar jaringan saraf dalam otak yang integritasnya tergantung pada asupan zat gizi yang cukup. ${ }^{25}$ Zat-zat gizi tersebut terdiri atas zat gizi makro (karbohidrat, protein, lemak) dan zat gizi mikro yaitu vitamin dan mineral. ${ }^{26}$

Pengaruh makanan terhadap perkembangan otak, apabila makanan tidak cukup mengandung zat-zat gizi yang dibutuhkan, dan keadaan ini berlangsung lama, akan menyebabkan perubahan metabolisme dalam otak dan berakibat terjadi ketidakmampuan otak berfungsi normal. Pada keadaan yang lebih berat dan kronis, kekurangan gizi menyebabkan pertumbuhan badan terganggu, badan lebih kecil diikuti dengan ukuran otak yang juga kecil. Jumlah sel dalam otak berkurang dan terjadi ketidakmatangan dan ketidaksempurnaan organisasi biokimia dalam otak. Keadaan ini berpengaruh terhadap perkembangan kecerdasan anak. $^{27}$

Status gizi bukanlah satu-satunya faktor yang mempengaruhi prestasi belajar sebagai indikator dari tingkat kecerdasan anak. Selain status gizi, prestasi belajar juga dipengaruhi oleh banyak faktor lainnya seperti faktor intelegensi, daya ingat, motivasi, lingkungan keluarga, sekolah dan masyarakat. ${ }^{28}$

\section{KESIMPULAN}

Terdapat hubungan antara kecerdasan emosional dengan prestasi belajar dan tidak terdapat hubungan antara status gizi dengan prestasi belajar siswa SMA Negeri Unggul Kota Subulussalam.

\section{SARAN}

Siswa diharapkan untuk menjadi pribadi yang terbuka dengan ikut berperan aktif dalam berbagai kegiatan ekstrakurikuler yang diselenggarakan di sekolah sebagai upaya untuk meningkatkan kecerdasan emosional. Bagi peneliti selanjutnya diharapkan penelitian dilakukan dengan jumlah sampel yang lebih banyak, menggunakan alat ukur lain, dan diharapkan dapat mengkaji faktor-faktor lain yang mempengaruhi prestasi belajar.

\section{REFERENSI}

1. Wasis D. Hubungan Intelegensi, Status Gizi dengan Prestasi Belajar siswa SLTP. Fakultas Kedokteran Universitas Diponegoro Semarang; 2001.

2. Setiawati M, Wijayanto P, Setiadi DW. Hubungan Kecerdasan Emosional, Status Gizi dengan Prestasi Belajar. Universitas Diponegoro Semarang; 2007.

3. Roy B. Emotional Intelligence and Academic Achievement Motivation Among Adolescents: a Relationship Study. J Arts, Sci Commer. 2013;(April 2013):126-30.

4. Hadi H. Beban Ganda Masalah Gizi dan Implikasinya Terhadap Kebijakan Pembangunan Kesehatan Nasional. Pidato Pengukuhan Jab Guru Besar. 2005;1-24.

5. Badan Penelitian dan Pengembangan Kesehatan. Riset Kesehatan Dasar (RISKESDAS) 2013. Lap Nas 2013. 2013;1-384.

6. Dwi Y, Irwanto, Wibowo A. The Relationship between Nutritional Status and Learning Achievement of School-Age Children in Elementary School. 2016;1(7):1-4.

7. Momongan MMH, Punuh MI, Kawatu PAT. Hubungan Antara Status Gizi dengan Prestasi Belajar Siswa SMA Negeri 11 Surabaya. J Pendidik [Internet]. 2013;1(2):54752. Available from: http://www.ejournal.unesa.ac.id

8. Amanda R. Korelasi Status Gizi dengan Siklus Menstruasi Pada Siswi SMA Negeri Unggul Kota Subulussalam Tahun 2016. Universitas Syiah Kuala; 2016.

9. Zaki RP. Perbedaan Tingkat Kecerdasan Emosional Antara Siswa Kelas III Pendidikan Reguler SMAN 3 Banda Aceh dan Siswa Pendidikan Asrama SMAN 10 Fajar 
Harapan Banda Aceh Tahun 2014. [Banda Aceh]: Universitas Syiah Kuala; 2014.

10. Fauzi F, Anggraini D, Dewiarti A, Sahli A. The Relationship Of Emotional Quotient And Nutritional Status With Learning Achievement On 22 nd Junior High School Bandar Lampung Student. :67-75.

11. Kalapriya $\mathrm{C}$, Anuradha K. Emotional intelligence and academic achievement among adolescents. Int J Adv Res Manag Soc Sci. 2015;4(1):11-7.

12. Goleman D. Apakah Kegunaan Emosi. Jakarta: PT Gramedia Pustaka Utama; 2014.

13. Daud F. Pengaruh Kecerdasan Emosional (EQ) dan Motivasi Belajar terhadap Hasil Belajar Biologi Siswa SMA 3 Negeri Kota Palopo. J Pendidik dan Pembelajaran [Internet]. 2012;19(2):243-55. Available from: http://journal.um.ac.id/index.php/pendidikan-dan-pembelajaran/article/view/3475

14. Padriyani SO dkk. Hubungan Status Gizi dengan Prestasi Belajar pada Siswa-Siswi SMAN 1 Padang Tahun Ajaran 2013/2014. Kesehat Andalas. 2014;3(3):473.

15. Mahardika S. Hubungan Pengetahuan Ibu Tentang Gizi Dan Tingkat Kehadiran Anak Balita Di Posyandu Dengan Status Gizi Anak Balita Di Desa Gedongan Kecamatan Colomadu Kabupaten Karanganyar. Fakultas Ilmu Kesehatan. 2016.

16. Ahmad S, Fatimah F. Hubungan Kebiasaan Sarapan Pagi dan Jajan dengan Status Gizi Anak Sekolah Dasar Yogyakarta. 2011;1-15.

17. Ristiyati ID. Hubungan antara Status Gizi dan Prestasi Belajar Murid SD Negeri di Kecamatan Tuntang Kabupaten Semarang. 2014; Available from: http://eprints.ums.ac.id/29444/

18. Qurniyawati E. Hubungan Kecerdasan Emosional Dengan Prestasi Belajar Pada Mahasiswa Program Studi D IV Kebidanan Jalur Reguler FK UNS Tahun Ajaran 2008/2009. Universitas Sebelas Maret; 2009.

19. Syatyawati R. Hubungan antara Status Gizi dengan Prestasi Belajar Anak Sekolah Dasar di Desa Grenggeng Kecmatan Karangar Kebumen. 2013;1-16. Available from: http://eprints.ums.ac.id/24354/12/NASKAH_PUBLIKASI.pdf

20. Andriani A. Kecerdasan Emosional ( Emotional Quotient) Dalam Peningkatan Prestasi Belajar. Edukasi. 2014;2(1):459-72.

21. Tjunjing S. Hubungan Antara IQ, EQ, dan AQ dengan Prestasi Studi Pada Siswa SMU. Indones Phys J. 2011;17(1):69-87.

22. Khairunisa. Hubungan Status Gizi dengan Indeks Prestasi Kumulatif Mahasiswa Akademi Kebidanan Bekasi tahun 2010. Gema Nusant. 2011;VI.

23. Suryabrata S. Pengembangan Alat Ukur Psikologis. Yogyakarta: Andi; 2010.

24. Soekirman. Ilmu Gizi dan Aplikasinya untuk Keluarga dan Masyarakat. Direktorat Jendral Pendidikan Tinggi: Departemen Pendidikan Nasional; 2008. 31-35 p.

25. Markam S. Dasar-dasar Neuropsikologis Klinis. Jakarta: CV Sagung Seto; 2009.

26. Georgieff MK. Nutrition and the developing brain: nutrient priorties and measurement. Am J Clin Nutr. 2007;85(Supplement):000S-000S.

27. Almatsier S. Prinsip Dasar Ilmu Gizi. Jakarta: PT Gramedia Pustaka Utama; 2009.

28. Soetjiningsih. Tumbuh kembang remaja dan permasalahannya. Jakarta: CV Sagung Seto; 2015. 